\title{
幼児における大震災の影響に関する研究 5
}

一長引く心理的問題に影響する要因一

○徳田克己 ${ }^{1} \cdot$ 水野智美 $^{1} \cdot$ 西館有沙 ${ }^{2}$

( 1 筑波大学医学医療系・ 2 富山大学人間発達科学部)

キーワード: 大震災 心理的問題 幼览

The Impact of the Great East Japan Earthquake on Children's Mental Health5

- Factors affecting children's psychological problems -

Katsumi TOKUDA ${ }^{1}$,Tomomi MIZUNO ${ }^{1}$ and Arisa NISHIDATE ${ }^{2}$

( ${ }^{1}$ University of Tsukuba, ${ }^{2}$ University of Toyama)

Key words: Earthquake psychological problems Children

\section{目 的}

これまでに、東日本大震災が子どもにどのような心理的な影響を 与えたか、また原発事故が子どもの生活にどのような影響を与えて いるかについて、一連の研究を行ってきた。茨城県内の保育所に勤 務する保育者を対象に、園児の心理的問題について明らかにした研 究（徳田ら，2011）、摇れがかなり大きく、一部に津波の被害があっ た茨城県内の地域（以下、準被災地）に住む保護者を対象に、子ど もに現れる心理的問題を明らかにした研究（徳田ら，2012）などで ある。これらの研究の結果、入眠困難や夜中に起きるなどの睡眠の 問題、余震のたびに泣く、大人に抱きつくなどの不安定な状態が長 く続いていることを確認した。

本稿では、準被災地に住む保護者および関東地方で津波の心配は なかったが強い摇れを体験した地域（以下、摇れた地域）に住む保 護者を対象にした調査を通して、幼児の心理的問題がどのような要 因に関係しているのかを明らかにしたいと考えた。

\section{方 法}

対象者 : 対象者は912名。そのうち、準被災地（日立市、鹿嶋市） に住む幼児を持つ保護者は 399 名、摇れた地域（杤木県、千葉県 内陸部、埼玉県）に在住する幼児を持つ保護者は 513 名。

手続き：幼稚園、保育所に協力を依頼し、無記名式・自記式の質問 紙調査を保護者に配布した。回収は留置法を用いた。調査時期は 2011 年 6 月であった。

調査項目 : 2011 年 3 月 11 日の本震の際の居場所 (1 項目)、震災に 関する子どもの発言（1 項目）、震災映像の視聴経験とその際の子 どもの様子 (2 項目)、地震や津波について保護者が子どもに伝え たこと（選択 6 項目、記述 1 項目）、子どもの心理的問題（選択 11 項目、記述 1 項目)、地震遊び等（選択 3 項目、記述 1 項目）。

\section{1. 居住地域}

\section{結 果}

子どもにみられる心身の状態 11 項目（余震の時に泣く、余震の時 に親に抱きつく、余震の時に不安そうにする、自分ひとりでいるこ とができない、夜の寝つきが悪い、頭痛や腹痛などの身体的な症状 が出る、夜に一人で寝られない、夜中に起きてしまう、夜驚、地震 があったら死ぬの?」と何度も尋ねる、園に行きたがらなくなる) について、本震から 1 か月以上継続していたと回答した項目が 4 項 目以上あった者 (以下、問題多群)、1〜3 項目であった者（以下、 問題少群)、1 項目もなかった者（以下、問題無群）に分けた。

その結果、問題多群は45名 (5\%)、問題少群 359名（39\%）、問 題無群 508 名 $(56 \%)$ であった。これらの3 群を居住地域で比較し てみると（表 1)、準被災地の子どもの方が問題行動を示す割合が高 いことを確認した（ $\left.\chi^{2}(2)=12.15, p<0.01\right)$ 。準被災地では、半 数の子どもが 1 つ以上の心理的な問題が 1 か月以上続いていた。

\section{2. 本震についての子どもの発言}

3月 11 日に大きく摇れたことについての子ども発言と問題行動と の関係をみると、「こわかつた」などの恐怖を表す発言をしていた子 どもは、そのような発言をしなかった子どもと比べて問題行動が継 続する割合が高かった（表 2)。一方、「がまんできた」「大丈夫だっ
た」などの落ち着きを表す発言をした子どもは、そのような発言が みられなかった子どもに比べて、問題行動が長引かないケースが多 かった $(p=0.018)$ 。本震の際に「ママが (先生が) 守るから大丈夫」 などと大人から声をかけられて、安心感を持つことができた子ども の方が、その後、問題行動を出現させていないことが確認できた。

\section{3. 地震や津波の被害に関するテレビ映像の視聴}

地震や津波による被害の映像を取り上げたテレビ番組の視聴の程 度と問題行動との関係をみると（表4）、映像を見なかった子どもの 方が問題行動を長引かせる割合が少ないことが確認できた $(p=0.046)$ 。地震の後には、幼児を日常の生活に早く戻し、不安を解 消させることの必要性が強調されている（TOKUDA, 2012）が、地 震や津波の映像を見せないようにすることも、子どもの不安を解消 するために必要なことである。

表1. 居住地域による違い

\begin{tabular}{rrrr}
\hline & 準被災地 & 摇れた地域 & $x^{2}$ 值 \\
\hline 問題多群 & $6 \%(25$ 名 $)$ & $4 \%(20$ 名 $)$ & \\
問題少群 & $44 \%(177$ 名) & $36 \%(182$ 名) & $12.15^{* *}$ \\
問題無群 & $49 \%(197$ 名) & $61 \%(311$ 名) & \\
\hline
\end{tabular}

（\%の母数は淮被災地399名、摇れた地域513名）** : $p<0.01$

表2. 本震時の子どもの発言 1 : 恐怖を表す発言

\begin{tabular}{|c|c|c|c|}
\hline & $\begin{array}{l}\text { 恐怖を表す } \\
\text { 発言あり }\end{array}$ & $\begin{array}{c}\text { 恐怖を表す } \\
\text { 発言なし }\end{array}$ & $x^{2}$ 值 \\
\hline 問題多群 & 8\%（34名） & 2\%（11名） & \multirow{3}{*}{$34.67^{* *}$} \\
\hline 問題少群 & 45\%（206名） & 33\%（153名） & \\
\hline 問題無群 & 47\% (210名) & 65\% (298名) & \\
\hline \multicolumn{3}{|c|}{ （\%の母数は恐怖を表す発言あり450名、発言なし432名） } & $* *: p<0.01$ \\
\hline 本震時 & どもの発言 2 : & ち着きを表す発言 & \\
\hline & 落ち着き & 落ち着き & Fisher \\
\hline & 発言あり & 発言なし & 直接確率 \\
\hline 問題多群 & $3 \%(2$ 名) & 5\%（43名） & \multirow{3}{*}{$0.018^{*}$} \\
\hline 問題少群 & $26 \%$ (20名) & 41\% (339名) & \\
\hline 問題無群 & 71\%（54名） & $54 \%$ (454名) & \\
\hline
\end{tabular}

(\%の母数は落ち着きを表す発言あり 76 名、発言なし836名) ${ }^{*}: p<0.05$

表4. 地震や津波に関するテレビ視聴

\begin{tabular}{|c|c|c|c|c|}
\hline & よく見た & 少し見た & 見なかった & Fisher \\
\hline 問題多群 & 6\%（21名） & 4\%（21名） & 0 & \\
\hline 問題少群 & $43 \%(152$ 名) & 38\%(193名) & 20\%( 3 名) & $0.046^{*}$ \\
\hline 問題無群 & $51 \%(180$ 名) & $58 \%(299$ 名) & $80 \%(12$ 名) & \\
\hline
\end{tabular}

